\title{
Települési környezetvédelem Magyarországon: Egy kutatás előfeltevései
}

\section{Local environmental protection in Hungary: A research hypothesis}

\author{
FODOR LÁSZLÓ, BARTA ATTILA, FÓNAI MIHÁLY, \\ BÁNYAI ORSOLYA
}

FODOR László: egyetemi tanár, Debreceni Egyetem, Állam- és Jogtudományi Kar; 4002 Debrecen, Pf. 400.; fodor.laszlo@law.unideb.hu

BARTA Attila: egyetemi adjunktus, Debreceni Egyetem, Állam- és Jogtudományi Kar; 4002 Debrecen, Pf. 400.; barta.attila@law.unideb.hu

FÓNAI Mihály: egyetemi tanár, Debreceni Egyetem, Állam- és Jogtudományi Kar; 4002 Debrecen, Pf. 400.; fonai.mihaly@law.unideb.hu

BÁNYAI Orsolya: egyetemi adjunktus, Debreceni Egyetem, Állam- és Jogtudományi Kar; 4002 Debrecen, Pf. 400.; banyai.orsolya@law.unideb.hu

KULCSSZAVAK: környezetjog, helyi önkormányzatok, ökológiai fenntarthatóság, helyi stratégia- és jogalkotás, közszolgáltatások

ABSZTRAKT: Az alábbi cikk a Nemzeti Kutatási, Fejlesztési és Innovációs Hivatal által támogatott, Helyi önkormányzati szerepek és eszközök az ökológiai fenntarthatóság megvalósításában címet viselő, alapvetően jogtudományi (de emellett szociológiai és politológiai) megközelítésű kutatás bevezető tanulmánya. Célja rögzíteni az interdiszciplináris kutatás hipotéziseit és várható eredményeit. Úgy véljük, hogy a helyi cselekvési szintnek az ökológiai fenntarthatóság elérésében játszott szerepe nélkülözhetetlen, habár nem egyedüli, és nem is az elsődleges tényező. Ha az önkormányzatok túl sok feladatot és hatáskört kapnak, akkor azokat nem tudják megfelelően ellátni, illetve a környezetpolitika, környezetjog egészének hatékonysága gyenge (hiszen számos probléma nem közelíthető meg helyi szinten). Ha túl kevés feladatuk, illetve hatáskörük van, akkor amellett, hogy csorbul a helyi önkormányzáshoz való jog, a környezetpolitika, illetve környezetjog összességében megint nem lesz eléggé hatékony. Egyensúlyt kell tehát találni valahol, ami a változó lehetőségek és kihívások függvényében nem egy statikus egyensúly, hanem csakis dinamikus egyensúly lehet, folyamatos súlypontváltoztatással. Abból indulunk ki, hogy környezeti fenntarthatósági szempontból jelenleg is számos változás indokolt, melyek részben intézményi, strukturális jellegűek. Úgy véljük, hogy a helyi közösségek igényei, érdekei és elvárásai sem hagyhatók figyelmen kívül, ezért a kérdéskör értelmezése során több aktor szempontjaival és cselekvéseivel kell számolni.

László FODOR: professor, Faculty of Law, University of Debrecen; Pf. 400., H-4002 Debrecen, Hungary; fodor.laszlo@law.unideb.hu

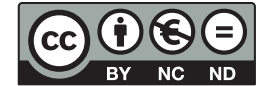


Attila BARTA: assistant professor, Faculty of Law, University of Debrecen; Pf. 400., H-4002 Debrecen, Hungary; barta.attila@law.unideb.hu

Mihaly FóNAI: professor, Faculty of Law, University of Debrecen; Pf. 400., H-4002 Debrecen, Hungary; fonai.mihaly@law.unideb.hu

Orsolya BÁNYAI: assistant professor, Faculty of Law, University of Debrecen; Pf. 400., H-4002 Debrecen, Hungary; banyai.orsolya@law.unideb.hu

KEYWORDS: environmental law, local governments, ecological sustainability, local strategy and law-making, public services

ABSTRACT: The following essay is an introductory study of the research "The Roles and Instruments of Local Governments in the Realization of Ecological Sustainability" - a primarily legal research, also involving social and political sciences, supported by Hungary's National Research, Development and Innovation Office (NKFIH).

The research heavily draws upon the assumption that Hungarian local governments have in-depth knowledge about environmental protection even though there is not any comprehensive analysis backing this argument. Our project then - as its main contribution - hopes to fill this knowledge gap about the degree and depth of local governments' knowledge considering environmental protection. However, it should be noted that only the legal interpretation of this topic is not enough, therefore - according to our research plan - in order to realize the before mentioned goal, mixed (both legal and empirical) research methods will be used at the same time. For instance, beside classic legal methods as legislative analysis, questionnaire research among 300 local governments, different focus group interviews, and - in order to have a really deep impression of the topic - fieldwork among 10-15 local governments will be carried out.

Accordingly, the essay's goal is to present both the above-mentioned research's basic assumptions and expected results. However, it should be noted, that because of the project's legal nature this research cannot be exhaustive in every detail.

Our opinion is that the local level plays an indispensable role in realizing ecological sustainability, although it is not the only factor (and is neither the primary one) in doing so. The reasons for this are that, first, environmental protection is considered to be a local affair and, second, that local governments possess several legal and non-legal tools to provide this duty. Notwithstanding, if local governments bear too many responsibilities and unnecessarily extended authorities, they will be unable to properly perform their duties, resulting in ineffective environmental law and policies (as several problems will not be approached on the local level). On the other hand, if the local governments receive a too limited set of responsibilities and authorities, their self-governance rights will be curtailed, with, eventually, the same result. The solution is to find a balance which - considering the ever-changing possibilities and challenges - cannot be a static, but rather a dynamic one. Therefore, according to the research's assumptions, several changes (e.g. institutional, structural) must be performed to support environmental sustainability. Considering that the demands, interests, and expectations of local communities cannot be neglected, aspects and actions of various actors also should be taken into account.

\section{Bevezetés}

A Debreceni Egyetem Állam- és Jogtudományi Karának tizenegy fős, különböző társadalomtudományokat és jogterületeket képviselő kutatócsoportja 2015 őszétől 2018 tavaszáig (30 hónapon át) azt vizsgálja, hogy vajon a hazai települési önkormányzatok milyen szerepet töltenek be a környezetpolitikában, illetőleg a környezetvédelmi jog alakításában és végrehajtásában. 
A különböző, egymásra épülő módszerekkel végzendő vizsgálat első lépéseként a legfontosabb központi jogszabályokat tekintettük át (az Alaptörvény, az önkormányzati törvény, a környezetvédelmi törvény mellett egyes ágazatok szakterületi szabályait is, amelyek önkormányzati kompetenciákat hoznak létre), vizsgálva a helyi és a központi szint egymáshoz való viszonyát, s feltártuk a jog- és államtudományi szakirodalmát e kérdéskörnek (pl. Balogh 2013; Fogarasi 2012; Hoffman 2014; Sólyom 2001). Több tucatnyi helyi önkormányzat saját rendeleteit, környezeti tárgyú programjait, rendezési terveit megvizsgáltuk (a Nemzeti Jogszabálytár önkormányzati adattára, illetve a helyhatóságok hivatalos oldalai alapján) - ez a kutatásnak továbbra is része, de a továbbiakban inkább kiegészítő jellegű a helyszínen végzett gyüjtőmunkához képest. Hipotéziseink többsége csak empirikus kutatásokkal igazolható, míg kisebb részük esetében - pl. éppen a helyi rendeletek tartalmát illetően - erre nincs feltétlenül szükség. Már most megállapítható, hogy a Nemzeti Jogszabálytár ${ }^{1}$ feltöltöttsége hiányos, a kisebb települések jelentős része nem rendelkezik saját honlappal, vagy ha igen, az nehezen áttekinthető, s mivel így a helyi rendeletek nyilvánossága nem érvényesül teljes körüen, esetenként a hatályos előírások feltárása is csak több módszer együttes alkalmazásával történhet meg.

Alkotmánybírósági és kúriai döntéseket, ombudsmani jelentéseket tekintettünk át a minél teljesebb feldolgozás igényével. Láthatóvá vált, hogy számos törvényességi és alkotmányossági probléma adódik, vélhetőleg a helyi és a központi szint közötti hatáskörmegosztás bizonytalanságaiból, a központi szabályok gyakori változásából, a megfelelő szakértelem hiányából, s más okokból is, amelyek azonban csak empirikus vizsgálatok s szakirodalmi kutatás útján ismerhetők meg.

A továbbiakban - a Települési Önkormányzatok Szövetségével és a Belügyminisztériummal történt kapcsolatfelvétel nyomán - valamennyi (azaz mintegy 3000) önkormányzatot igyekszünk megszólítani online kérdőívünkkel (a TÖOSZ felajánlotta részvételét a koordinálásban, a BM az Önkormányzati Hírlevelet mint fórumot, illetőleg valamennyi aktuális önkormányzati elérhetőséget és alapadatot rendelkezésünkre bocsátotta). Az online kérdőív eredményességét ezek a kapcsolatfelvételek minden bizonnyal javítják. Tervünk az, hogy országosan legalább 300 települési önkormányzatot ténylegesen bevonva nyerjünk képet a települési önkormányzatok szerepéről, aminek az érdekében - reprezentatív mintaválasztáson alapuló megkeresés során - a települések leginkább érintett tisztségviselőit személyesen is megkeressük a kérdőívvel. A mintaválasztási elvek esetében a településtípus mellett a települések környezeti állapotát, „érintettségét” is figyelembe vesszük. ${ }^{2}$ Tucatnyi településen és kerületben ${ }^{3}$ mélyfúrásokat végzünk, elsősorban fókuszcsoportos interjúk készítésével (Greenbaum 2000; Marshall, Rossman 1999; Taylor, Bogdan 1998; Vicsek 2006). Önmagában a ,jogi” értelmezés nem képes az összetett kérdéskör magyarázatára; arra törekszünk, hogy minél mélyebb és érvényesebb tudást és képet nyerjünk az önkormányzatok szerepéről a környezetvédelemben. A településeket az esetleges térségi eltérések megvilágítása érdekében egyenletes földrajzi 
eloszlásban jelöljük ki, de a településtípusok és a térbeliség szempontja mellett a környezeti problémák meglétét is figyelembe vesszük. Az interjúalanyok körébe (részint a látókör bővítése, részint a megfelelő kontrollvizsgálatok érdekében) a szakterület más szereplöit - így pl. az ombudsmani hivatalt, szakosodott ügyvédi irodákat, az érdekelt kutatóhelyeket, illetve több, szakmailag érintett társadalmi szervezetet - is bevonjuk (az első kapcsolatfelvételek sikeresen megtörténtek). Valamennyi helyszínen, ahol interjút készítünk, egyúttal terepmunkát végzünk: feltárjuk és összegyüjtjük a kapcsolódó jegyzőönyveket, szerződéseket, egyéb, nem nyilvános dokumentumokat, illetőleg szükség esetén további, személyes interjúkat veszünk fel, újabb szereplők bevonásával.

Az általunk kiemelt mintegy tucatnyi településről esettanulmányokat készítünk. Első lépésben - a szakirodalom, az interneten elérhető önkormányzati és médiaadatok felhasználásával - előtanulmányok készülnek, amelyek az interjúkat és a terepmunkát hivatottak megalapozni. A második lépésben - az empirikus kutatási eredmények feldolgozásával - állnak elő a publikálás igényével készülő esettanulmányok. Ezekben az önkormányzatok rendeleteinek és eljárásrendjének, a bizottsági és testületi, szakértői anyagoknak, koncepcióknak a tartalomelemzésén túl a helyben felmerülő környezeti és környezetvédelmi kérdéseknek a vizsgálatára is törekszünk, érintve a helyi nyilvánosság és a helyi társadalom müködésének, a helyi döntéshozatali mechanizmus elemzésének a problémáit.

A vizsgálati tárgykörhöz kapcsolható szakterületeken - pl. a közszolgáltatások joga, településrendezés, az önkormányzati hatáskörök alakulása, helyi stratégiaalkotás, a helyi környezetpolitikai cselekvési szint közgazdaságtani és politológiai megközelítése, településkutatás, fenntarthatóság, helyi klímapolitika, intelligens városok (smart cities), városfejlesztés - elvégzett korábbi kutatások, szakmai publikációk eredményeit is igyekszünk hasznosítani. Ugyanakkor számot kell vetnünk azzal, hogy 2012/13-tól olyan változások következtek, következnek be az önkormányzati szektorban, amelyek a szakirodalmi eredményeknek a környezetvédelemre vonatkoztatott kiegészítése mellett azok újragondolását is szükségessé tehetik.

A gyűjtött adatok feldolgozása számos olyan eredményt - összefoglaló adatokat, általános helyzetértékelést, hazai és külföldi cselekvési mintákat, intézkedési javaslatokat - ígér, amelyeket a helyi környezetvédelmi ügyek szabályozása, tervezése, intézése során maguk az önkormányzatok is hasznosithatnak, ugyanakkor ehhez szükség van az érintettek - különösen a bevonni kívánt önkormányzati szervek, vezetők - nagyfokú együttműködési készségére. Arra is igyekszünk rámutatni, hogy a központi kormányzat mindezt miként segítheti elő. Az alábbiakban röviden összefoglaljuk azokat az elöfeltevéseinket, szakirodalmi ismereteinket és egyéb kutatási tapasztalatainkat, amelyek indokolttá teszik a települési környezetgazdálkodás, illetve -védelem jogi és közpolitikai kereteinek és gyakorlatának a felmérését, s az eredményeknek a szakmai közönséggel való megosztását.

Abból indulunk ki (következő rész), hogy a környezetvédelemben a helyi cselekvési szint különös figyelmet, egyúttal szakmai támogatást is igényel, amit 
hazánkban ma egyfelől a szabályozás és a közszolgáltatások terén látható központosítás, másfelől a központi kormányzat környezeti érzékenységének a csekély foka húz alá (Horváth 2015; Szigeti 2014). ${ }^{4}$ Ebből fakad első vizsgálati tárgykörünk, az önkormányzati szerepek feltérképezése (a Kutatási kérdések és hipotézisek rész 1-3. hipotézise). A központi, illetve dekoncentrált szerveket és a helyi önkormányzati feladatokat, kompetenciákat normatív (szabályozó), szolgáltató, programozó, végrehajtó szerepekre bontjuk, s néhány kiválasztott területen (környezetvédelmi ágazatban) közelebbről megvizsgáljuk. A kérdéskör alkotmányjogi háttere, egyúttal legáltalánosabb szabályozási kerete viszonyítási alapként szolgál ehhez (4. hipotézis), hiszen a kompetenciák végső soron az Alaptörvényből vezethetők le. Különböző, jogilag (s esetenként szociológiailag is) értelmezhető problémákat vetünk fel, amelyeket párba állítunk valamilyen eszközzel (pl. rossz döntések - környezeti vizsgálat, környezeti igazságtalanság - településrendezés, átfogó szemlélet hiánya - programozás, sajátos környezetállapot - szigorúbb szabályozás), a kérdés majdani megválaszolásának igényével (5-11. hipotézis). Fontosnak tartjuk annak vizsgálatát is, hogy vajon a jelenlegi struktúrák mennyiben alkalmasak az olyan, napjainkban gyarapodó problémák kezelésére, mint a klímaváltozás (12. hipotézis). A kutatás során végül nézzük azt is, hogy tipizálható-e e téren az önkormányzatok attitüdje (13. hipotézis).

\begin{abstract}
Aktualitás
A helyi cselekvési szintnek az ökológiai fenntarthatóság (a környezeti fenntarthatóság erős vagy szigorú követelménye; vö. Bándi 2013; Szirmai 2006; Tosics 2006) elérésében játszott szerepe világszerte egyre jelentősebb, ami szoros összefüggésben van azzal a - nemzetközi jogi, európai uniós és nemzeti dokumentumokban, politikai deklarációkban és stratégiai tervekben ${ }^{5}$ egyaránt megfogalmazódó - felismeréssel, hogy a környezetgazdálkodásban a legkevesebb igénybevétellel és terheléssel az olyan társadalmi-gazdasági rendszerek müködése jár, amelyek a helyi erőforrások észszerű hasznosítására épülnek (Gyulai 2007). A helyi erőforrásokkal való felelős, ésszerü, fenntartható gazdálkodás egyik garanciája, ha a velük kapcsolatos döntések - legalábbis részben - helyben (a mi olvasatunkban a település, illetve a kistérség szintjén) születnek, azokban a helyi közösségek aktívan részt vesznek:" érdeklődnek, információval rendelkeznek, beleszólásuk van - pl. véleményük kifejezése révén - a döntések meghozatalába (utóbbi megközelítést járja körül Glied, Pánovics 2012).

A Magyarország helyi önkormányzatairól szóló 2011. évi CLXXXIX. törvény (a továbbiakban röviden: Mötv.) általános - környezetvédelmi szempontokra ki nem hegyezett - megközelítésében „A helyi önkormányzat feladatai ellátása során (...) erősíti a település önfenntartó képességét, feltárja lehetősé-
\end{abstract}


geit és hasznosítja saját erőforrásait.” Ez a körülírás egy aktív, cselekvő önkormányzat képét vetíti elénk, amelyik a helyi adottságokra tudatosan épít. A helyi relevanciájú feladatok rendezéséhez az önkormányzatok jogi - pl. rendeletalkotás, hatósági eljárások - és nem jogi eszközöket - pl. képzés, környezeti tudatformálás (Szabó 2008), civil szervezetek támogatása, helyi gazdaságszabályozás - egyaránt igénybe vehetnek. Ebben a munkában mi elsősorban a jogi eszközöket vizsgáljuk.

A környezeti problémák jelentős része abból fakad, hogy a társadalom tagjai egymástól és a természettől eltávolodva, elidegenedve mind a velük/azokkal kapcsolatos rálátásukat, mind pedig felelősségérzetüket (szolidaritásukat) elveszítve, hétköznapi életük (fogyasztói, tulajdonosi, termelési stb.) szokásait, preferenciáit saját egyéni kényelmükhöz, civilizációs igényeikhez (pl. a divathoz, virtuális valósághoz) vagy épp (pl. természeti erőforrások kivitelével) a globális tőkeérdekekhez igazítják, ami mára köztudottan nem fenntartható sem környezeti, sem gazdasági, sem pedig társadalmi szempontból. Ezért magától értetődően szükséges a környezetpolitika helyi/települési közösségi szintjének, autonómiájának a biztositása, illetve adott esetben a megerősítése, az élhetőbb környezet és az igazságosabb társadalom megteremtése, illetve a negatív globalizációs jelenségek visszaszorítása érdekében. Törekedni kell a természet és társadalom egységének helyreállítására: „A természet és a társadalom közötti harmonikus kapcsolat kialakítására képes, új társadalmi és gazdasági paradigmák helyi szinten bontakoznak ki és erősödnek meg" (Antal 2015, 39.).

Az önkormányzatok és vezetőik gyakran egyszerre kénytelenek képviselni a beruházók és a lakosság (környezeti) érdekeit (Heady 2001; Jreisat 2012). Különösen a településrendezési eljárásokban nő az igény arra, hogy az önkormányzati vezetők (a polgármesterek) mintegy közvetítőként (mediátorként) is fellépjenek. Erre - az eltérő közérdekek egyidejü érvényesítésére - azonban nincsenek kondicionálva, amire az utóbbi évek gyakorlati tapasztalatai - pl. az EMLA Környezeti Management és Jog Egyesület jogi képviseleti és szakértői tevékenysége (Gajdics 2014) - vagy a sajtó hírei alapján lehet következtetni. Másik oldalról közelítve kérdés, hogy a döntéshozók milyen látens eszközökkel, a különböző értékek milyen irányú manipulációjával próbálják meg az emberek beállítódását, preferenciáit úgy formálni, hogy elkerüljék a nyílt és rejtett konfliktusokat (Bachrach, Baratz 1962).

A helyi szint megerősítése - s azon keresztül a sokféleség, az alulról jövő kezdeményezések -, a bizonyos mérvủ decentralizáció mellett olyan rendszerszintü (részben jogi) elvek és érvek is szólnak, mint a szubszidiaritás vagy azzal összefüggésben a napjainkban - méltán - hangsúlyozott reziliencia (rugalmas ellenállási képesség). Az olyan kihívásoknak, mint a Kárpát-medencét jelentős mértékben fenyegető klímaváltozás társadalmi és gazdasági rendszerünk (miként a természeti rendszer maga) csak kellő rugalmassággal tud megfelelni. Minél ki- 
sebb, önállóan is működőképes egységekből áll egy rendszer, annál reziliensebb (Bándi 2013; Stern é.n.; Szirmai 2005; VAHAVA 2010).

$A z$ önkormányzatok, ha nem is egyedüli szervezeti keretei a helyi szintü termelési-fogyasztási rendszereknek, egységeknek (arra a gazdálkodó szervezetek, egyesületek, egyházközségek vagy akár az önálló jogalanyisággal nem bíró kezdeményezések is alkalmasak lehetnek), kétségtelen, hogy a helyi hatalomgyakorlásnak, közösségszervezésnek, ellátásnak - s így a fenntarthatóságnak is - nélkülözhetetlen, meghatározó aktorai, számos esetben katalizátorai. Szerepük kezdettől fogva politikai és költségvetési viták kereszttüzében áll, amivel természetesen a szakirodalom is foglalkozik (Horváth 2007; Pálné Kovács 2008).

A környezetvédelem terén útkeresésüknek számtalan jelét láthatjuk. Megjelentek a helyi klímastratégiák, a fenntarthatóságot és a településüzemeltetési költségeket csökkentő energetikai beruházások, amelyekről az a tapasztalat, hogy szoros összefüggésben állnak a településrendezési feladatokkal és a pénzügyi szempontokkal, de meghatározó motivációs tényező a települési vezetők hozzáállása is (Kozma et al. 2014). Számos önkormányzat együtt gondolkodik bizonyos feladatokról, pl. a Klímabarát Települések Szövetsége keretei között (Antal 2015). ${ }^{7}$

A helyi kezdeményezéseknek a sora ezzel szerencsére nem ér véget, de szót kell ejteni a központi intézkedésekról is. 2011-től kezdve, a területi kormányhivatali rendszer kiépülésével egyidejűleg a hatósági hatásköröknek elindult az önkormányzatoktól (jegyzőktől) a járási hivatalokra telepítésének a folyamata, ami környezetvédelmi hatásköröket is érint (pl. levegőtisztaság-védelmi hatósági ügyek). Éppen emiatt érdemes vizsgálni azt, hogy ez milyen hatással jár a helyi vonatkozású ügyek intézésére, ${ }^{8}$ illetve ha nem teljesen kielégítő eredményességről szólnak az első évek tapasztalatai, akkor vajon a feltárt folyamatok tükrében hogyan lenne javítható az összkép.

A kutatás általános (a kormányzati intézkedésektől, finanszírozási helyzettől, újabb környezeti kihívásoktól független) indokoltságát adja továbbá, hogy hazánkban az önkormányzati környezetpolitikai (környezetvédelmi szabályozási, igazgatási) szint vizsgálatára komplex megközelítésben mindeddig nem került sor. A rendelkezésre álló ismeretek ezért hiányosak és jelentős részükben el is avultak. Az előzmények, háttérismeretek közül kiemelendő, hogy a jövő nemzedékek országgyűlési biztosának (2008-2012) gyakorlata jelentős mértékben hozzájárult a helyi környezeti konfliktusok térképének felvázolásához. ${ }^{9}$ Az Alkotmánybíróság számos területen vizsgálta és értékelte az önkormányzati szabályozás kereteit (hulladékgazdálkodás, természetvédelem, vízgazdálkodás, településrendezés). Egy-egy részterületen (pl. a települési hulladékgazdálkodás magyar modelljei, vízgazdálkodás, természetvédelem) készültek tudományos elemzések is (Bándi 1999; Enyedi 2000; Kerekes, Kiss 2004; Metzinger 2001; Nagy 2009; Pump 2013; Szilágyi 2012). 


\section{Kutatási kérdések és hipotézisek}

1. Az Alaptörvény a területet illetően komplex szemlélettel rendelkezik. Az „alkotmányos környezetjog" a környezethez való jogot olyan alapjognak tekinti, amely az emberi élethez való jog fizikai feltételeit hivatott biztosítani, lényegében annak objektív, intézményi oldalának része (ehhez lásd még a 4. kérdésfelvetésünket). Emiatt egyfelől különösen nagy jelentősége van a prevenciónak, tekintettel arra, hogy az utólagos kárrendezés egyáltalán nem biztos, hogy képes az eredeti állapot helyreállítására. Másfelől az állam - ez alatt értve természetesen az önkormányzatokat is - aktív jelenléte kívánatos annak érdekében, hogy az intézményvédelmi oldal jól működjön (Fodor 2006). ${ }^{10}$ Ahogyan a környezet védelmének általános szabályairól szóló 1995. évi LIII. törvény (a továbbiakban Kvt.) 37. § (1) bekezdésében megállapítja, a környezet védelmének jogi szabályozását, a környezet védelmével összefüggő jogok és kötelezettségek megállapítását és megtartásuk ellenőrzését, a környezet védelmének tervezését és irányítását az állam és a helyi önkormányzat szervei látják el. A törvény külön fejezetben rögzít szabályozási, együttműködési, intézkedési jogköröket az önkormányzatok javára, de ezen felül hatósági (pl. engedélyezési), tervezési, információs jogosítványokat, illetve kötelezettségeket is találunk. A vízgazdálkodástól az építésügyön át a hulladékgazdálkodásig számtalan szakterület központi előírásai ezt továbbiakkal egészítik ki.

Az önkormányzatoknak a jelenleg hatályos jogszabályokban szereplő jogosítványai tehát rendkívül tág vizsgálati tárgykört jelentenek (a szorosan kapcsolódó építésügyi, földművelésügyi és egyéb hatáskörök nélkül is mintegy 130 kifejezetten környezet- és természetvédelmi hatáskörről van szó kormany.hu). Sem a jogszabályok, sem az azokat végrehajtó önkormányzatok nem használnak ki azonban valamennyi lehetőséget.

Álláspontunk szerint ez azzal magyarázható, hogy Magyarországon a környezetvédelmi igazgatás és eszközrendszer alapvető jellemzője a centralizáció, ami azt eredményezi, hogy a súlypont összességében az állami/államigazgatási feladatokon van. A helyhatóságok szabályozási és hatósági jogköreit vizsgálva rögzíthető, hogy - egyes közhatalmi jogosítványoktól eltekintve - elsősorban „szoft” eszközökkel rendelkeznek, azaz leginkább a helyi partnerség és kooperáció előmozdítói, katalizátorai lehetnek az ökológiai fenntarthatóság és klímavédelem terén. Miután a helyi önkormányzatok saját, önálló hatáskörrel alig rendelkeznek, szerepük inkább kiegészítő jellegü, illetve a központi államtól átruházott jogkörben történő közreműködés.

Ennek tartalmát illetően a jelenlegi közigazgatási jogi szabályozás, így például (a Mötv. 13. §-a alapján) a helyi környezet- és természetvédelem, valamint a vízgazdálkodás és vízkárelhárítás nevesített feladatain túl explicite sem az ökológiai fenntarthatóság, sem pedig a klímavédelem nem jelenik meg. Ugyanakkor indirekt módon, a településfejlesztésen és -rendezésen keresztül igenis léteznek fenntarthatósági, valamint klimatikus célok és szempontok. Nincs ez 
másként az építésügyben sem, hiszen a természeti mellett az épített környezet védelme is szerves kötődést mutat a vizsgált területtel.

Hipotézisünk, hogy a települési önkormányzatok a szakterület csekély részét szabályozzák, a központi környezeti jogszabályok közül pedig elsősorban azokat ismerik és érvényesítik, amelyekkel valamilyen probléma kapcsán érdemben foglalkozniuk kell (Fónai 2012).

2. Az önkormányzatok környezetvédelmi hatáskörei a rendszerváltást követően egyre gyarapodtak, miközben a feladatok ellátásának a szakmai garanciái számos esetben nem voltak biztosítottak. Volt olyan jogalkotói elképzelés, amelyik a polgármesteri hivatalok belső struktúráját is érintve környezetvédelmi szakemberek alkalmazását írta volna elő, de ez akkor az önkormányzatiság alkotmányos elvének a csorbulása okán nem érvényesülhetett. A rendszerváltást követően kiépülő jogvédelmi rendszer, a törvényességi kontroll mechanizmusai rengeteg problémát hoztak felszínre a formálódó önkormányzati környezetvédelmi intézményrendszer működéséről, ami többek között tájékozatlanságon alapult. Ahogyan 1993-ban a kormány sem tudta, milyen környezetvédelmi szabályozást kellene életbe léptetnie a jogalkotónak (lásd a 996/G/1990 sz. AB határozatot), úgy az önkormányzatok sem tudták, hogy a gombamód szaporodó feladat- és hatáskörökkel miképp kell vagy lehet élni.

Számos esetben írtak elő ágazati törvények véleményezési jogot, pl. a területileg illetékes zöldhatóság javára, ami azonban a gyakorlatban többnyire formális volt (több alkotmánybírósági határozat született, amelyik a véleményezési jog megsértése miatt semmisített meg önkormányzati rendeletet). ${ }^{11} \mathrm{Az}$ is hamar kiderült, hogy az önkormányzati környezetvédelmi hatóságok számos hatáskörükkel nincsenek tisztában, illetőleg hogy széles körben volt törvénysértő e hatáskörök gyakorlása (erre különösen az ombudsmani jelentések hívták fel a figyelmet). Arra is fény derült, hogy a helyi környezeti konfliktusok jelentős részének érdemi megoldása csak beruházásokkal (pl. csatornázás, elkerülő út kiépítése, a közösségi közlekedés fejlesztése) lehetséges, amihez az önkormányzatok jellemzően nem rendelkeznek forrásokkal. (Amennyiben pedig támogatást - pl. európai uniós forrást - szereznek, illetve megfelelő beruházót találnak, pl. elkerülő út építésére, akkor annak érdekkörében olyan további beruházások - mint az elkerülő út mellett megvalósítandó logisztikai központok, raktáráruházak - történnek, amelyek újabb környezeti konfliktusok forrásai lehetnek. A környezeti konfliktusok áttevődnek más hatásviselőre, pl. természeti értékek kerülhetnek veszélybe. ${ }^{12}$ )

A környezeti érdekek és a magánérdekek elválasztása, megkülönböztetése egymástól sokszor egyszerüen lehetetlen, de az önkormányzatoknak azzal is szembesülniük kell, hogy a környezeti érdekek sokfélék, s egyidejü érvényesítésük nem mindig lehetséges. A NIMBY-jelenséggel való küzdelem sem mindig sikeres („ne az én kertem végébe” - emlékezhetünk többek közt a veszélyeshulladék-égető vagy az akkumulátorfeldolgozó terveivel az önkormányzatoknál házaló beruházók esetére). Úgy véljük, az ilyen érdekek egyeztetése több szakmaiságot és 
nagyobb rálátást igényel, mint amellyel pl. egy kistelepülés önkormányzata rendelkezhet (a méret és szakértelem problematikájára lásd Pálné Kovács 2008). Bizonyos feltételekkel ezért elfogadhatónak tartjuk, ha ilyenkor - a magasabb társadalmi érdekre tekintettel - az állam kap mozgásteret, amint az pl. a nemzetgazdasági érdekből kiemelt beruházások esetében lehetséges (lásd autópálya-építés).

Hipotézisünk az, hogy a települési önkormányzat mérete, a szóba jöhető szakemberek száma és szakmai összetétele is alakítja a helyi környezeti döntések és politika színvonalát és szakmaiságát. Ugyanakkor feltételezzük, hogy a szakemberhiány a járási hivatalokra történő feladattelepités révén kevesebb problémával jár a korábbiaknál (Szigeti 2014).

3. Éppen tíz éve írtuk, hogy a környezetvédelem terén tapasztalható végrehajtási deficit egyik melegágya az önkormányzati rendszer. Nem általában az önkormányzatiság, ${ }^{13}$ hanem az, ahogyan hazánkban megvalósult, ideértve azt is, hogy erre a szintre miként kerültek környezetvédelmi feladatok. A több mint 3000 önálló helyi önkormányzat számos telepített és tipikusan önkormányzati jellegű környezetvédelmi feladatot kapott, amelyek gyakorlására - ellenőrzési kapacitás hiányában - sem hivatalból, de sokszor még állampolgári kezdeményezés nyomán (panaszokra, kérelmekre) sem került sor. A birtokvédelemtől a levegőminőség-védelmen át a helyi vízgazdálkodásig számos területen jelentkeztek ilyen problémák (ezek egy részét az ombudsman hivatalból vizsgálta). Az okok közt lehetett számon tartani a hatáskörök túlzott mennyiségét, ellátásuk finanszírozásának elégtelenségét, a személyi és tárgyi feltételek hiányát, az érdektelenséget és ellenérdekeltséget (pl. az iparűzési adóból vagy az ingatlanértékesítésből fakadó bevételek, vagy egyéb gazdasági érdekeltség miatt sokszor a rövid távú beruházói érdekek jutottak inkább érvényre a közösség hosszú távú - nem csak környezeti - érdekeivel szemben). ${ }^{14}$ Azt is meg kellett állapítani, hogy a helyi szabályozási feladatok nem vagy nem megfelelő teljesítése (pl. a településrendezés anomáliái) révén a helyi közhatalom birtokosai (a polgármesterek) könnyebben vehették rá a hatósági feladatot ellátókat (a jegyzőt) a törvényi előírások megszegésére. Ebben persze közrejátszhatott, hogy helyi szinten nem került sor a hatalommegosztás olyan tartalmú szabályozására, mint az az alkotmányban a központi hatalomgyakorlás szervei, ágai közt megvalósult (előzményként lásd Fodor 2005).

A megoldást 5-10 évvel ezelött sokan egy olyan önkormányzati reformban keresték, amely a feladatok ellááára való alkalmasságot növelte volna, s többek közt a szabályozási és végrehajtási feladatok elválasztását, a regionális szint megerősödését, a finanszírozási modell átalakítását foglalta volna magában. A reformok indokoltsága több tekintetben sem volt kétséges (pl. a törvényességi ellenőrzés gyengesége, a középszint hiánya, az elaprózottság és egyéb szerkezeti problémák miatt), a 2010-es kormányváltást követően azonban olyan reform valósult meg, amely (pl. a közszolgáltatások, a hatósági jogkörök, a megyei önkormányzati vagyon állami feladatkörbe, tulajdonba kerülésével) a területi 
kormányhivatalok kiépülése és a hatósági hatáskörök koncentrálása révén a szereplők pozíciójának átalakulásával, az önkormányzatok autonómiájának csökkenésével, szerepcsökkenésével járt együtt (Pálné Kovács 2014). Ez a tendencia - a bevezetőnkben említett fenntarthatósági követelményekkel ellentétes irányban fejtve ki hatásait - nyilvánvalóan érinti a környezeti ügyeket. Feltételezhető, hogy az önkormányzati szervek és a fóvárosi/megyei/járási kormányhivatalok közötti együttműködés (pl. a szakhatósági közreműködés, a hatáskörrel bíró szervnél eljárás kezdeményezése, véleményezési jogkörök gyakorlása révén) elvben alkalmas az ebből fakadó hátrányok egy részének kiküszöbölésére. Ugyanakkor a közelmúltban megélt szervezeti átalakítások miatt az optimális múködés eléréséhez, az új intézményrendszer beüzemeléséhez még időre van szükség.

Ezen a ponton is érdemes arra utalni, hogy Európában léteznek a hazaitól eltérő modellek. Így pl. a helyi önkormányzatokat a német jogrend egészen másként kezeli. Ha kétely merül fel valamely feladat önkormányzati szintű ellátásának a hatékonysága felől, akkor nem azt a megoldást választják, hogy elvonják tőlük a feladatot: ők úgy gondolják, többre mennek, ha - tiszteletben tartva az önkormányzati autonómiát, a helyi demokrácia kereteit - megadják hozzá a megfelelő eszközöket, vagy egyéb módon hozzák helyzetbe az önkormányzatokat (Fodor 2015).

Azt várjuk, hogy a környezetvédelmi kérdések kezelése a kormányhivatalok kialakításával szakszerübbé válik, ugyanakkor eltávolodik a településektől, és kevésbé érzékeny a helyi kérésekre és érdekekre.

4. Az Alaptörvény XXI. cikk (1) bekezdése ugyanolyan, egészséges környezethez való jogot deklarál mindenki számára. Nyilvánvaló azonban, hogy az olyan településeken, amelyeken egészségkárosító környezeti ártalmaknak (szmognak, zajterhelésnek, sugárzásnak, balesetek veszélyének stb.) van kitéve a lakosság vagy annak egy része, ez a jog nem érvényesül megfelelően. E téren tehát ténylegesen nem élvezheti mindenki egyenlően az alapvető jogát.

Kiugróan egészségkárosító balesetekről, ipari katasztrófákról, több évtizedes szennyezések felhalmozódó terheiről hallva legtöbbször eszünkbe jut valamilyen kompenzációs eszköz, amely rendelkezésre áll: a környezeti kármentesítéstől és a helyreállítás egyéb jogi eszközeitől kezdve a környezetvédelmi intézkedési programok elfogadásán és végrehajtásán keresztül a terület- és településrendezés lokális intézkedéseiig, a hatósági korlátozásoktól a módosított környezetminőségi határértékeken át az együttmúködési megállapodásokig, önkéntes lakossági akciókig vagy a vagyoni viszonyok helyreállítását és a személyiségben bekövetkezett károk kompenzálását szolgáló kártérítésig. Ezek egy része az önkormányzatok mozgásterére esik: a környezethez való jog kötelezettjei (az államon belül) az önkormányzatok is. De vajon van-e az érintett települések önkormányzatainak több eszköze (s nagyobb kormányzati segítség áll-e rendelkezésükre)? Az ideális az volna, ha ezek - és a környezetpolitika többi szereplője kezében lévő - eszközök együttesen a környezeti rendszer egyensúlyát, illetve az ember és környezet közti kapcsolat harmóniáját valóban helyreállítani, biztosítani tudnák. 
Azt feltételezzük, hogy a több problémával szembesülő településeknek nincs több jogi eszközük mint másoknak, és megfelelő kormányzati segítséget sem feltétlenül kapnak.

5. A problémák mellett számos településen éppen az átlagnál kedvezőbb környezeti állapot, a kiemelt védelemre érdemes természeti értékek jelenléte és megőrzésének igénye, a pozitív helyi (fenntarthatósági) kezdeményezések indokolnának sajátos fellépést. Arra is tudunk példákat, amikor a helyi környezeti érdek valamely másik érdekkel (pl. idegenforgalom, rekreáció) együtt válik olyan értékké, amelyet az önkormányzat érvényesíteni szeretne.

Mindezeknek elvben megfelelhet egy önkormányzat, ha az országosnál szigorúbb előírásokat állapít meg saját közigazgatási területén. Ehhez az önkormányzatok jogalkotási jogkörét a Kvt. 48. § (1) bekezdése kiszélesíti: rendeleteik eltérhetnek az országos normától, amennyiben szigorúbb („,kizárólag nagyobb mértékben korlátozó”) környezetvédelmi előírásokat határoznak meg. Ha tehát egy önkormányzat úgy gondolja, hogy illetékességi területén az országosnál komolyabb követelményeket kíván érvényesíteni, akkor anélkül szigoríthatja az országosan irányadó feltételeket, hogy ellentétbe kerülne a magasabb szintű jogszabállyal, vagyis megsértené a jogforrási hierarchiát. A gyakorlatban gyakran élnek ezzel az önkormányzatok, pl. a zajvédelem körében (Metzinger 2001). (Amennyiben az országos előírást enyhítik, az önkormányzati rendelet alkotmánysértő. ${ }^{15}$ )

A Kvt. a szigorítás feltételéül szabja, hogy törvény vagy kormányrendelet az önkormányzat számára eltérést engedjen (meghatározott módon és mértékben). Az Alkotmánybíróság az önkormányzatok szigorítási jogosítványát eredetileg közvetlenül az Alkotmány környezetvédelmi rendelkezéséből (18. §, amelynek jelenleg az Alaptörvény XXI. cikk (1) bekezdése feleltethető meg) vezette le. A testület korai határozatai szerint - mivel a környezetvédelem helyi közügynek minősül - a szigorítás lehetősége független a törvényben, kormányrendeletben adott felhatalmazástól, ráadásul akkor is megilleti az önkormányzatot, ha nem kifejezetten környezetvédelmi tárgykörről, hanem a környezeti szempontoknak másik tárgykörben (mint pl. a vízi közlekedés vagy az állattartás rendjében) való érvényesítéséről van szó. ${ }^{16}$ Úgy tűnik azonban, hogy az AB később ezt a megközelítést elvetette, hasonló határozatok ugyanis nem születtek, s újabban inkább az önkormányzatok mozgásterének korlátait komolyabban vevő döntésekről van tudomásunk. Ezt a kérdést is érdemes azonban megvizsgálni, különös tekintettel arra, hogy az újabb kihívásként érvényesülő klímavédelem a helyi szintet is érinti (pl. a hőszigetekre, a különböző fütési módok eltérő károsanyag-kibocsátására, a megújuló energiák helyi kiserőmüveinek sajátos tervezési igényeire tekintettel). ${ }^{17}$ Nyilvánvaló, hogy ebben az esetben is a környezethez való jog és a jogállamiság alkotmányos követelményeinek kiegyensúlyozott érvényesítésére kell törekedni, figyelemmel a helyi önkormányzáshoz való jogra, amelyet az Alaptörvény (elődjével ellentétben) ugyan nem deklarál (Balázs 2014), de nem is ignorál teljesen. 
A helyi önkormányzatok szigorúbb környezetvédelmi szabályozása kapcsán azt várjuk, hogy annak lehetösége és szerepe gyengült (Fodor 2016).

6. A valóság sokszor igen távol esik az ideától, amit nem kívánt események mellett nem egyszer olyan állami, illetve önkormányzati intézkedések (pl. településrendezési döntések, beruházások) fokoznak, amelyeknek negatív környezeti hatásai vannak. Ezek a hatások sokszor előre láthatók, hatásvizsgálatokkal elkerülhetők, csökkenthetők lennének. Sajnos azonban a különböző stratégiai (ipari, közlekedési, energetikai, településrendezési, illetve területfejlesztési és egyéb szakterületekre tartozó) tervek előzetes vizsgálatát szolgáló „környezeti vizsgálat" nem tölti be a szerepét (Mezei, Suvák, Varjú 2013; Varjú 2010). Feltételezzük, hogy ennek okai közt szabályozási problémák is vannak (pl. a vizsgálandó tervek jogi jellege és egymáshoz való viszonya nem mindig egyértelmű, a tervezés és a vizsgálat keretei formálisak).

7. Ráadásul immár hazánkban is foglalkozni kell a környezeti igazságtalanság (környezeti rasszizmus) jelenségével, ami azt jelenti, hogy bizonyos környezeti ártalmaknak kisebbségi népcsoportok, egyébként is hátrányos helyzetű települések lakói fokozottabban ki vannak téve a többieknél (Málovics 2012). Emblematikusnak tekinthető ebből a szempontból a közkifolyók lezárásának ügye 2013-ból, amellyel kapcsolatban ombudsmani vizsgálat állapította meg, hogy az egészséges ivóvízhez való jog s azon keresztül az élethez való jog sérelme mellett közvetett, származáson alapuló diszkrimináció valósult meg, amikor az önkormányzat önkényesen (valós indok nélkül, aránytalan intézkedéssel) lezárta a település közterületi vízvevő helyeit (AJBH 2014). Még nyilvánvalóbb a probléma környezeti vonatkozása, amikor a lakosság alacsony életszínvonala, kedvezőtlen jövedelmi viszonyai egyszerre jelentkeznek a rossz környezeti állapot hatásaival, a környezeti javakhoz, illetve közszolgáltatásokhoz való hozzáférés nehézségeivel, de esetenként az is megfigyelhetö, hogy ilyen területeken könnyebb ártalmas beruházásokat megvalósítani, vagy épp az ártalmas tevékenységből származó adóbevétel nem ahhoz a településhez folyik be, amelyiken az ártalmak jelentkeznek. ${ }^{18}$

Azt feltételezzük, hogy egyelőre sem a kormányzat, sem az önkormányzatok nem érzékenyek a környezeti rasszizmus problémájára, holott utóbbiaknak különösen a településrendezés során jogi eszközük is lenne erre.

8. Az önkormányzati környezetvédelem nemcsak a szabályozás, tervezés, végrehajtás (jogalkalmazás) jellemzően közhatalmi színezetű jogköreiben, hanem szervezési, gazdálkodási feladatokban (magánjogi és közmenedzsmenteszközök révén) is szerephez jut. Az önkormányzati környezetgazdálkodás alkotmányjogi alapjai megváltoztak a közelmúltban: a 2012-től hatályos Alaptörvény többek közt az önkormányzati tulajdonnal összefüggésben is megemlékezik a fenntartható fejlődés követelményéről. Hogy ennek megvannak-e, változtak-e időközben a törvényi garanciái (pl. a nemzeti vagyonról szóló 2011. évi CXCVI. törvényben), miként reagáltak erre az önkormányzatok, szintén időszerü kérdés. 
Az Alaptörvény 38. cikke - amely szerint (az állam és) a helyi önkormányzatok tulajdona nemzeti vagyon; kezelésének és védelmének célja a közérdek szolgálata, a közös szükségletek kielégítése és a természeti erőforrások megóvása, valamint a jövő nemzedékek szükségleteinek figyelembevétele - arra vezethető vissza, hogy a környezet elemei és szolgáltatásai (az igénybevételükhöz szükséges infrastruktúrával együtt) közjavak. E közjavaknak csupán egy része van köztulajdonban, e tulajdonformának ugyanakkor - pl. a környezetvédelem közigazgatási szabályozása mellett - nagy a jelentősége a környezetvédelemben (pl. az önkormányzati tulajdonban álló föld vagy a víz védelmében). ${ }^{19} \mathrm{Az}$ Alaptörvény intenciója mögött áll feltételezésünk szerint az a tapasztalat is, amely szerint az önkormányzatok nem feltétlenül jó gazdái a rájuk bízott természeti erőforrásoknak, vagyongazdálkodási szabályaikban nincs nyoma a fenntarthatóságnak. ${ }^{20}$

9. Az önkormányzatok közszolgáltatási feladatai jelentős átalakuláson esnek át napjainkban. Témánk szempontjából leginkább a települési vízgazdálkodás és hulladékkezelés területét érdemes kiemelni, ahol kezdettől fogva szabályozási problémák merültek fel alkotmányjogi szempontból (pl. hogyan szabályozhatja az önkormányzat a közszolgáltatás díját), ${ }^{21}$ és a szolgáltatás gyakorlata, infrastruktúrájának elmaradottsága is okozott problémákat (az egyes szolgáltatások, illetve vagyonelemek tekintetében eltérő mértékben). A szektorban jelenleg zajló államosítás (az állami szerepvállalás egyaránt meghatározóvá válik az energia-, a vízés közcsatorna-ellátási, a hulladék- és településgazdálkodási, a közútfenntartási, valamint a helyi tömegközlekedési feladatok ellátásában) és központosítás nyilvánvalóan kihat az önkormányzati feladatellátásra (Horváth 2015, 209.). Töredékére csökkent azon gazdálkodó szervezetek száma, amelyekkel a feladatellátásra az önkormányzatok szerződhetnek, ugyanakkor a kiválasztás szempontjai szigorodtak az elmúlt években (pl. a többségi állami vagy önkormányzati tulajdon elöírása a hulladékkezelési közszolgáltató cég esetén, a hulladékról szóló 2012. évi CLXXXV. törvény alapján).

A hulladékkezelési ágazatban ma nehezen belátható, átmeneti helyzetről beszélhetünk, a kormányzati tervek szerint változik még a díjszabás (bár máig nem született meg a miniszteri rendelet a díjmértékről, az önkormányzati szabályozási mozgástér mégis korlátozott, részben a rezsicsökkentéssel összefüggésben) és a díjbeszedés módja is (abba harmadik félként belép az állami koordináló szervezet). Hogyan látják vajon az önkormányzatok, javult-e ezzel a szolgáltatásbiztonság, illetőleg a szolgáltatások hatékonysága? Egyelőre, mint az közismert, többszáz településen a katasztrófavédelmi hatóság kijelölése alapján tudják csak biztosítani a közszolgáltatást, és több milliárd forintnyi tőke hiányzik az ágazatból (Csepregi 2015). A víziközmü-szolgáltatások terén is lezajlott a köztulajdont (az állami és önkormányzati közműtulajdont) kizárólagossá tévő centralizáció (Szilágyi 2014), de egyelöre a szükséges (s az önkormányzatok által többnyire elhanyagolt) infrastruktúra-beruházások nem kerülhettek közelebb (Pálné Kovács, Finta 2014, 65.), s abban sem vagyunk biztosak, hogy mindennek során a környezetvédelmi szempontok érdemi szerepet játszottak. 
Feltételezzük, hogy egy átmeneti javulást követően - ami a tulajdonjogra vonatkozó előírás előnyeivel járt együtt (Pálné Kovács, Finta 2014, 60.) - csökken az önkormányzatok jogi (szabályozási, szerződéses, tervezési) befolyása a feladatellátás szervezésére, minőségére.

10. A kutatás további hipotézise, hogy a helyi cselekvési szint megfelelő (a nemzetközi elvárásoknak és trendeknek, illetve az uniós jognak megfelelö, hatékony, szakmailag megalapozott, fenntartható, koherens) kialakítása, illetve megerősítése csak integrált megközelítésben lehetséges, ami azonban hazánkban nem érvényesül. (Az integráció kérdéséhez a környezetvédelmi igazgatásban lásd Bándi 1995; Fodor 2000, 13-18.; Jávor, Németh 2008.) Össze kellene kapcsolódnia egymással a helyi rendeletalkotás, a programozás (Pálné Kovács, Finta 2013, 65), a közigazgatás, a közszolgáltatás-szervezés, a vagyongazdálkodás és a közösségszervezés feladatrendszereinek, s nem utolsósorban az önkormányzatok példamutatásának is (Szlávik 2005). Az egyes környezeti elemek (természeti erőforrások) átfogó (holisztikus) megközelítése szükséges; illetve egy-egy szakterületen belül is (pl. vízgazdálkodás, hulladékgazdálkodás) rendszerszerü, valamennyi életciklust figyelembe vevő környezetgazdálkodás és -védelem indokolt. Mindezek legáltalánosabb kerete a programalkotás lehetne, ami feltételezésünk szerint sokszor formális, a törvényi elöirásoknak való minimális megfelelést szolgálja, s a különböző stratégiák közti összhang nem biztositott kellően.

11. A társadalmi szervezeteknek az önkormányzatokkal való viszonyát már kutatták korábban, s megállapították, hogy a rendszerváltás első éveihez képest csökkent a helyi társadalmi szervezetek lendülete, illetve e szervezeteket a helyi hatalom képviselői gyakran inkább célcsoportnak vagy ellenpontnak tekintik, mintsem partnernek (Pálné Kovács 2008, 258-259.). Mi nem foglalkozunk általánosságban ezzel a kérdéssel, de úgy gondoljuk, hogy annak vannak sajátosságai a környezetvédelemben (amennyiben ti. az ország nemzetközi és uniós kötelezettségei körében megjelenik a társadalmi részvétel számos intézménye). A kutatás hipotézise az is, hogy az elmúlt években bekövetkezett jogszabályváltozások - az új Alaptörvény, önkormányzati törvény, víziközmü-szolgáltatási törvény, hulladéktörvény stb., illetve a közigazgatást érintő szervezeti átalakítások; a társadalmi környezet -, a civil szervezetek aktivitásának csökkenése, a külföldi szervezetek megjelenése; és nem utolsósorban az uniós (infrastrukturális) támogatások (tervezés, kivitelezés, illetve a felhasznált pénzek ellenőrzése) radikálisan megváltoztatták, illetve változtatják a helyi környezetpolitika kereteit. Ennek nyomának kell lennie a lakossággal való kommunikációban, a civil szervezetekben való együttmüködésben (a jogalkotás, a stratégiaalkotás, a közérdekü adatokról való tájékoztatás során stb.) is.

12. Mindemellett új, környezeti kihívásként a helyi önkormányzatok szintjén is megjelent a klímaváltozás, illetve az azzal kapcsolatos védekezés, pl. az energiagazdálkodás, a vízgazdálkodás terén, és a felkészülés, pl. a településrendezés, építésügyi igazgatás terén (Schmidtke 2012). Tekintettel arra, hogy ebben a körben az önkormányzatoknak általános és közvetlen hatáskö- 
reik nincsenek, a rendelkezésre álló levegőminőség-védelmi eszközök (parkolási rend, környezeti zóna kialakítása, dugódíj, kerékpárutak kiépítése, helyi építésügyi szabályok stb.) csupán részmegoldásokhoz vezethetnek (Bányai 2014). Nemzetközi példák mutatják, hogy vannak olyan sikeres helyi kezdeményezések (pl. helyi vagy regionális energiatermelési és -elosztási modellek), amelyek egyszerre szolgálják az energiahatékonyság, a környezetvédelem és a fenntarthatóság céljait, miközben megfelelnek a helyi fejlesztésekkel szemben támasztott általános követelményeknek (helyi erőforrásokra támaszkodnak, helyi igényekhez igazodnak, hozzájárulnak a helyi lakosság életminősége javításához) is (Bärenbrinker 2012; Fodor 2014a, 189-201.). Ezekben a projektekben általában fontos a helyi önkormányzatok szerepe, hazánkban azonban (bár pl. a földrajzi adottságok megfelelőek lennének) kevés hasonló jó gyakorlatot találunk. A mozgástér ugyanis korlátozott, tekintettel a szabályozási környezetre vagy épp az önkormányzati pénzügyi és vagyoni háttérre (Zsibók 2013, 7-8.).

Azt várjuk, hogy Magyarországon a települési önkormányzatok klímavédelmi politikája szegmentált, jellegzetesen valamely szempontot vagy érdeket érvényesiti, illetve a helyi szabályozási mozgásteret az általános (nemzeti) energiapolitikai szempontok szükre méretezik.

13. Az önkormányzatok között a környezeti ügyek vitelében megmutatkozó különbségek alkalmasak lehetnek arra, hogy a települési önkormányzatokat tipizáljuk. Alighanem léteznek olyanok, amelyek a puszta jogszabály-végrehajtó szerepét töltik be, vagyis az országos, magasabb szintü jogszabályokban rájuk nézve kötelező jelleggel megállapított feladatokat igyekeznek ellátni, több-kevesebb sikerrel, de ezen túl menő aktivitásra erejük nem terjed ki. Szintén bizonyos értelemben kényszerként megélt impulzus nyomán sejlik fel az a köre a helyi önkormányzatoknak, amelynek a települései az utóbbi évtizedekben komoly környezeti konfliktusok helyszínei voltak, netán ma is azok. Harmadik csoportot képezhetnek azok, amelyek igyekeznek önálló aktoraiként szerepelni a környezetpolitikának, ami megmutatkozik különböző programjaikban, terveikben, önkormányzati szövetségekhez való tartozásukban, rendeleteik tartalmában, a lakossággal való kommunikációjukban, netán környezetvédelmi tanúsítvánnyal is rendelkeznek stb. A három csoport között merev határokat nem feltételezünk.

\section{Záró gondolatok}

Az önkormányzati környezetvédelem témaköréről való ismereteink széles körüek ugyan, de átfogó vizsgálaton alapuló, tudományos elemzések nem láttak napvilágot ebben a témakörben. Kutatásunk reményeink szerint e hézagnak egy jelentős részét töltheti be. 
A hazai helyi önkormányzati rendszer kétszintű (megyei, illetve települési önkormányzatok), de azon belül érdemi mozgástere a települési önkormányzatoknak van (a megyei önkormányzatok koordináló, véleményező, programozó szerepköre jóval gyengébb), magától értetődőnek tűnik ezért középpontba állításuk. Úgy véljük, hogy helyi környezetpolitikáról csak akkor beszélhetünk, ha a különböző közhatalmi (pl. rendeletalkotási), magánjogi (tulajdonosi) és formális jogi kereteken kívüli eszközök összekapcsolódnak, ezért a számos környezetvédelmi államigazgatási hatáskört átvevő (járási) kormányhivatalokat önállóan nem vizsgáljuk.

Az általunk felvetett problémák, tendenciák, környezetvédelmi és környezetgazdálkodási szakterületek - noha távolról sem jelentenek hiánytalan állapotfelvételt - jól érzékeltetik, hogy rendkívül izgalmas, ugyanakkor meglehetősen kiterjedt tárgykörről van szó. Természetszerűleg a mi kutatásunk sem lehet minden részletre kiterjedő. Annál inkább nem törekedhetünk ilyesmire célkitűzéseink meghatározásakor, mert a kutatás alapvetően jogi szempontú. Ugyanakkor a későbbi fázisokban is számítanunk kell még olyan kérdések felmerülésére, amelyek mellett nem mehetünk el szó nélkül.

Összefoglalva úgy látjuk, hogy az önkormányzati szint nélkülözhetetlen, ha nem is az egyedüli, és - a jelenlegi jogi, illetve politikai rendszerünkben nem is az elsődleges - tényezője a környezetvédelemnek. A környezetvédelem helyi közügy, a helyi közügyek ellátására pedig az önkormányzati szerveknek számos különböző - jogi és jogon kívüli - eszközük van.

Ha az önkormányzatok túl sok feladatot és hatáskört kapnak (a hozzáértésükhöz, a finanszírozáshoz, a többi szint feladataihoz képest), akkor azokat nem tudják megfelelően ellátni, illetve a környezetpolitika, környezetjog egészének hatékonysága gyenge (hiszen számos probléma nem közelíthető meg helyi szinten). Ha túl kevés feladatuk vagy hatáskörük van (a helyi közösségek igényeihez, a fenntarthatóság szempontjaihoz, a helyben felmerülő és kezelendő konfliktusokhoz, kihívásokhoz képest), akkor amellett, hogy csorbul az önkormányzatiság alkotmányos elve, a környezetpolitika és környezetjog összességében megint nem lesz eléggé hatékony. Egyensúlyt kell tehát találni valahol, ami a változó lehetőségek és kihívások függvényében nem statikus egyensúly, hanem csakis dinamikus egyensúly lehet, időszakonkénti súlypontváltoztatással. Kormányzati szintű (szabályozási, finanszírozási, szervezési) feladat az egyes alrendszerek és cselekvési szintek közötti munkamegosztás kereteinek a meghatározása, amelynek gyakorlása során célszerü igazodni a mindenkori környezeti, társadalmi és gazdasági adottságokhoz. Abból indulunk ki, hogy környezeti fenntarthatósági szempontból jelenleg is számos változás, az önkormányzati kompetenciák erősítése lenne indokolt, amire van lakossági igény, s amely alkotmányjogi, rendszertani, hatékonysági és más érvekkel is alátámasztható. 


\section{Jegyzetek}

http://www.njt.hu/njt.php?onkormanyzati_rendeletek Az online kérdőív 2016 júniusától ittérhető el: http://evasys.unideb.hu/evasys/online.php?p=UG411 A helyszínek meghatározása során magától értetődő volt Debrecen kiválasztása, de Hajdúböszörményé is (utóbbié nemcsak a földrajzi közelség miatt, hanem mert az önkormányzatnál több kutatást végeztek karunk munkatársai). Emellett eltérő méretű, gazdasági-társadalmi helyzetű, illetve környezeti adottságú községek, városok, kerületek (több budapesti kerület mellett Biharkeresztes, Bogács, Dorog, Győr, Lakitelek, Pécs, Siófok, Tiszaújváros) kerültek célkeresztbe, az ország különböző területeiről.

A környezetvédelem vonatkozásában zajló közigazgatási szervezeti átalakításokhoz lásd még az Országos Környezetvédelmi Tanács állásfoglalását az Alkotmánybíróság II/2092-8/2015. ügyszámú megkeresésére, Budapest, 2016. január 7. (http://www.oktt.hu/).

Hazai szinten pl. Nemzeti Környezetvédelmi Program, Nemzeti Erdőprogram, Nemzeti Éghajlatváltozási Stratégia, Nemzeti Éghajlatváltozási Program, Nemzeti Energiastratégia 2030, Nemzeti Fenntartható Fejlődés Stratégia és számos jogszabály, újabban pl. a földforgalmi törvény preambuluma; uniós szinten az Agenda 2000 (1997) vagy a közös agrárpolitika 2015-től végrehajtandó reformjának frissen elfogadott koncepciója; nemzetközi szinten az Agenda $21 \mathrm{stb}$.

A hazai vonatkozásokra lásd a jövő nemzedékek országgyűlési biztosának 2010. évi beszámolóját (Fülöp 2011).

Csak érdekességként: e szövetségnek jelenleg mintegy 30 tagja van, míg a hasonló szervezetnek a szomszédos Ausztriában immár 300 feletti a tagsága. Az igényeket felismerve az Energiaklub „önkormányzati szolgáltatásokat” nyújt képzések, kutatás, stratégiakészítés formájában (Energiaklub).

Mennyiben csökken az önkormányzatok mozgástere, sikerül-e a helyi közérdeket megfelelően érvényesíteni, szakmailag megalapozottabb döntések születnek-e (megfelelően figyelembe veszik-e a környezeti és egyéb érdekeket), azaz tekinthetőek-e a kormányzati intézkedések a helyi környezetvédelmi igazgatás javítására tett lépéseknek?

Pl. a 2008-2009. közötti időszakról szóló beszámoló (Fülöp 2010) kifejezetten megemlékezik a környezeti konfliktustérkép jelentőségéről, s számtalan helyi vonatkozású példával támasztja azt alá.

Erre vonatkozóan az Alkotmánybíróság 28/1994. (V. 20.) határozatán túlmenően lásd különösen a 2219/H/2001. sz., a 252/B/1999. sz., a 258/B/1999. sz., az 1051/B/1999. sz., a 893/H/1996. sz., a 48/1997. (X. 6.) sz., a 46/2001. (XI. 17.) sz. 484/B/1996. sz., a 34/1996. (VII. 9.) sz., a 26/1997. (IV. 25.) sz., a 43/1997. (VII. 1.) sz., az 52/1998. (XI. 27.) sz., az 53/1998. (XI. 27.) sz., az 54/1998. (XI. 27.) sz., az 55/1998. (XI. 27.) sz. vagy az 56/1998. (XI. 27.) sz. AB határozatokat.

Pl. a 11/2008. (I. 31.) AB határozat és a 16/2008. (II. 28.) AB határozat.

Tipikus példa a csapadékvíz elvezetésének hiánya, pl. az OBH 2789/2001. sz. ügyben (2001. IX. 23.) vagy az OBH 5096/2006. számú ügyben (2007. VII. 24.). Az elkerülő utak problematikájára különösen a jövő nemzedékek országgyülési biztosa hívta fel a figyelmet (Fülöp 2010, 154.; Fülöp 2011, 85-89.)

Ámbár azt sem hallgattuk el, hogy a környezetvédelmi hatásköröknek az önkormányzatokra való telepítését más országokban is problematikusnak ítélték meg korábban a környezetvédelmi deficitek szempontjából (Czybulka 1996).

Ennek egyik tipikus példája rajzolódik ki az Alkotmánybíróság 48/1997. (X. 6.) sz. határozatában. A gyakorlatban nem egy esetben tapasztaljuk, hogy az önkormányzat enyhíti a vízminőségi határértéket annak érdekében, hogy egy-egy ipari vállalkozás szennyvize a közcsatornába kerülhessen, de az a szélesebb körben elterjedt gyakorlat is vitatható, hogy - növényvédelmi indokokra való hivatkozással - megengedik a tarló égetését, amit egyébként a levegővédelmi kormányrendelet (jogszabály eltérő rendelkezéséhez kötött kivételtől eltekintve) kifejezetten megtilt (Fodor 2014b, 242.).

Szép példa erre a szarvasi önkormányzat esete, amelynek rendelete a vízi közlekedés rendjé- 
hez kapcsolódó korlátozásokat vezetett be a Holt-Körösre, s amelyet az AB megalapozottnak talált: 2219/H/1991. sz. AB határozat.

17 Lásd pl. a 28/2011. (III. 31.) AB határozatot és a 49/2011. (VI. 9.) AB határozatot.

18 Korábban a Védegylet végzett környezeti igazságosság címszó alatt ilyen tárgyú kutatásokat (pl. Encs, Sajószentpéter, Mezőcsát kapcsán készültek esettanulmányok), de Bódvalenke esete is közismert példa (ahol pl. a háztartások jelentős része nem csatlakozott a csatornahálózatra). Az adóbevétel és az ártalmak helyének diszkrepanciájára a 2010-es vörösiszap-katasztrófa lehet példa, Ajkát, Kolompárt és Devecsert érintve (Védegylet 2010).

19 Lásd különösen az AB 28/1994. (V. 20.) és 16/2015. (VI. 5.) sz. határozatait az állami tulajdon vonatkozásában, vagy az 1380/H/1996. sz. határozatot, amely a halászati jog korlátozhatóságát állapítja meg önkormányzati tulajdonban lévő vízterületen.

20 Nem képezi a kutatás tárgyát az a feltételezésünk, hogy ma kevesebb természeti erőforrással (pl. földvagyonnal) rendelkeznek, mint a rendszerváltás idején. E feltételezett vagyoncsökkenés a feladatok ellátásához szükséges finanszírozási források kiegészítésének az igényéből fakadhatott. Ugyanakkor úgy tűnik, hogy más tekintetben (pl. vízi közművek) ellentétes irányú folyamatok zajlottak az utóbbi években, és hogy (különösen a környezetterhelési díjak megtartása érdekében) örvendetesen gyarapszik az önkormányzati pénzügyi alappal rendelkező települések száma, ami az alapok elkülönített kezelésének kötelezettségére tekintettel jelentős forrásképző lehet.

21 Noha e tekintetben 2013-tól elvben miniszteri rendeleti szintre került a díjszabás, a probléma nem oldódott meg maradéktalanul; miniszteri rendelet még nincs, s az önkormányzatok e téren továbbra sem mindig teljesítik a jogállamiságnak megfelelő módon szabályozási kötelezettségüket (Szilágyi 2015).

\section{Köszönetnyilvánítás}

A Helyi önkormányzati szerepek és eszközök az ökológiai fenntarthatóság megvalósításában címet viselő, K 115530 nyilvántartási számú kutatási projektet a Nemzeti Kutatási, Fejlesztési és Innovációs Hivatal támogatja.

\section{Irodalom}

AJBH [Alapvető Jogok Biztosának Hivatala] (2014): Beszámoló az alapvető jogok biztosának és helyetteseinek tevékenységéról 2013. Budapest. http://www.parlament.hu/irom39/13837/pdf/ajbh beszamolo_hu_2013.pdf (Letöltés: 2016.január 21.)

Antal Z. L. (2015): Klímaparadoxonok. Lehet-e harmónia természet és társadalom között? L'Harmattan, Budapest

Bachrach, P., Baratz, M. S. (1962): Two faces of power. The American Political Science Review, 4., 947-952. http://doi.org/b2sqzb

Balázs I. (2014): Az önkormányzatokra vonatkozó szabályozás átalakulása. MTA Law Working Papers, 3., 1-12.

Balogh Zs. (2013): Az önkormányzati rendeletek törvényességi kontrollja. Új Magyar Közigazgatás, 5., 37-42.

Bándi Gy. (1995): Variációk a környezetvédelmi igazgatás témájára. Magyar Közigazgatás, 10., 577-586.

Bándi Gy. (szerk.) (1999): Önkormányzati környezetvédelmi kézikönyv. KJK, Budapest

Bándi Gy. (2013): A fenntartható fejlődés jogáról. Pro Futuro, 1., 11-30. 
Bányai O. (2014): Energiajog az ökológiai fenntarthatóság szolgálatában. DELA, Debrecen

Bärenbrinker, V. (2012): Nachhaltige Stadtentwicklung durch Urban Governance. Duncker\&Humblot, Berlin http://doi.org/bnjc76

Csepregi I. (2015): A hulladékgazdálkodási közszolgáltatás metamorfózisa. In: Gajdics Á., Szilágyi Sz. (szerk.): A magyar környezetvédelmi jog 20 éve. EMLA, Budapest, 20-21. http://emla.hu/sites/ default/files/EMLA\%2020_kiadvany.pdf (Letöltés: 2015. december 20.)

Czybulka, D. (1996): Umweltschutzdefizite und Verwaltungskultur. Juristenzeitung, 2., 596-602.

Energiaklub: Önkormányzatok. Az Energiaklub önkormányzati szolgáltatásai. http://www.energiaklub.hu/ onkormanyzatok (Letöltés: 2016. január 10.)

Enyedi Gy. (szerk.) (2000): Magyarország településkörnyezete. MTA, Budapest (Magyarország az ezredfordulón)

Fodor L. (2000): Integratív környezetjog az Európai Unióban és Magyarországon. Bíbor Kiadó, Miskolc

Fodor L. (2005): A hatékonyság kérdése és a végrehajtási deficit jelensége a környezetvédelmi szabályozásban. In: Fodor L. (szerk.): A környezetvédelmi jog és igazgatás hatékonyságának aktuális kérdései. DE ÁJK, Debrecen, 17-51.

Fodor L. (2006): Környezetvédelem az Alkotmányban. Gondolat, DE ÁJK, Budapest

Fodor L. (2014a): Klímavédelem az energiajogban - szabályozási modellek Németországból. Wolters Kluwer Complex Kiadó, Budapest

Fodor L. (2014b): Környezetjog. Debreceni Egyetemi Kiadó, Debrecen

Fodor L. (2015): Kommunális környezetvédelem német szemmel. Pro Futuro, 2., 159-165.

Fodor L. (2016): A helyi szabályok eltérése a központi előírásoktól - környezetvédelmi megfontolások. Jogtudományi Közlöny, 7-8., 353-364.

Fogarasi J. (2012): A helyi önkormányzatok és a jogharmonizáció néhány összefüggése 1990-2012 között II. Comitatus, 209., 34-70.

Fónai M. (2012): Potential impacts of community problems and residential needs on local politics. In: Bódi, F., Fábián, G., Lawson, T. (eds): Local organisation of social services in Hungary. Studies in comparative social pedagogies and international social work and social policy. Europäischer Hochschulverlag, Bremen, 78-103.

Fülöp S. (2010): Beszámoló a jövő nemzedékek országgyúlési biztosának 2008-2009. évi tevékenységéról. http://beszamolo.jno.hu/?menu=beszamolo09 (Letöltés: 2016. január 21.)

Fülöp S. (2011): Beszámoló a jövő nemzedékek országgyülési biztosának 2010. évi tevékenységéról. J/2416. http://beszamolo2010.jno.hu/JNO_beszamolo_2010.pdf (Letöltés: 2015. december 12.)

Gajdics Á. (szerk.) (2014): Településfejlesztés - Településrendezés. Jogi útmutató civil szervezetek számára. EMLA, Budapest http://emla.hu/sites/default/files/Telepulesfejlesztes_telepulesrendezes_ final.pdf (Letöltés: 2015. december 12.)

Glied V., Pánovics A. (szerk.) (2012): ...Cselekedj lokálisan! - Társadalmi részvétel környezeti ügyekben. PTE ÁJK, Publikon, Pécs

Greenbaum, T. (2000): Moderating focus groups. Sage, Thousand Oaks

Gyulai I. (2007): Új megközelítések a fenntarthatóság érdekében. In: Kóródi M. (szerk.): Remény a fennmaradásra. Kossuth Kiadó, Budapest, 225-240.

Heady, F. (2001): Public administration. A comparative perspective. Marcel Dekker, New York

Hoffman I. (2014): Az önkormányzati rendeletek bírósági felülvizsgálata a Kúria Önkormányzati Tanácsa gyakorlata tükrében. Magyar Jog, 6., 347.

Horváth M. T. (2015): Magasfeszültség - Városi szolgáltatások. Dialóg Campus, Budapest, Pécs

Horváth M. T. (szerk.) (2007): Piacok a fótéren: Helyi kormányzás és szolgáltatásszervezés. KSzK ROP, Budapest

http://www.kormany.hu/hu/dok?source=1\&type=301\#!DocumentBrowse (Letöltés: 2015. október 21.)

Jávor B., Németh K. (2008): Reformok, megszorítások és a környezetvédelem hatósági rendszere. Politikatudományi Szemle, 3., 35-60.

Jreisat, J. (2012): Globalism and comparative public administration. CRC Press, Boca Raton

Kerekes S., Kiss K. (szerk.) (2004): Megkérdőjelezett sikerágazat, MTA, Budapest

Kozma G., Kulcsár B., Molnár E., Teperics K., Pénzes J., Radics Zs. (2014): Az energiatakarékos építkezésekkel kapcsolatos társadalmi kérdések. In: Kalmár F. (szerk.): Fenntartható energetika megújuló energiaforrások optimalizált integrálásával. Akadémiai Kiadó, Budapest, 379-390. 
Málovics Gy. (2012): Környezetvédelem vagy társadalmi igazságosság? Kovász, tavasz-tél, 3-31.

Marshall, C., Rossman, G. B. (1999): Designing qualitative research. Sage, London

Metzinger É. (2001): Önkormányzati rendeletalkotás a környezetvédelemben, figyelemmel a BácsKiskun megyei tapasztalatokra. In: Bándi Gy. (szerk.): A környezetvédelmi jogalkotás és jogalkalmazás időszerü kérdései. PPKE JÁK Környezetjogi és Versenyjogi Tanszék, Budapest, 73-86.

Mezei C., Suvák A., Varjú V. (2013): Környezetvédelem és energetika a települési önkormányzatoknál a Dél-Dunántúlon - Egy empirikus kutatás eredményei. In: Zsibók Zs. (szerk.): Önkormányzati energetikai fejlesztések: Nemzetközi körkép és a dél-dunántúli tapasztalatok, MTA KRTK Regionális Kutatások Intézete, Pécs, 142-160.

Nagy J. (2009): Közigazgatás-szervezési és kodifikációs kihívások a helyi jelentőségű védett természeti területek kapcsán. Új Magyar Közigazgatás, 9., 16-29.

Pálné Kovács I. (2008): Helyi kormányzás Magyarországon. Dialóg Campus, Pécs, Budapest

Pálné Kovács I. (2014): Az önkormányzati rendszer és a területi közigazgatás átalakulása 2010-2013. MTA Law Working Papers, 2., 1-9.

Pálné Kovács I., Finta I. (szerk.) (2013): A helyi önkormányzati közszolgáltatások jogi szabályozási és szakpolitikai környezete. Zárótanulmány. MTA KRTK RKI, Pécs, http://arop.rkk.hu/ (Letöltés: 2016. május 12.)

Pálné Kovács I., Finta I. (szerk.) (2014): Összefoglaló tanulmány a projekt keretében készült 50 települési esettanulmány fóbb tapasztalatairól. MTA KRTK RKI, Pécs, arop.rkk.hu:8080/Dokumentumok/ 10_zarotaneset.pdf (Letöltés: 2016. május 12.)

Pump J. (2013): Közszolgáltatási modellek a hulladékgazdálkodásban. In: Horváth M. T. (szerk.): Kilengések: Közszolgáltatási változások. Dialóg Campus, Budapest, Pécs, 139-172.

Schmidtke, P. K. (2012): Kommunaler Klimaschutz. Metropolis, Marburg

Sólyom L. (2001): Az alkotmánybíráskodás kezdetei Magyarországon. Osiris, Budapest

Stern, N. (2006): Stern-jelentés. Az éghajlatváltozás közgazdaságtana. Vezetői összefoglaló. http://www. greenfo.hu/hirek/hirek_item.php?hir=15126 (Letöltés: 2016. január 28.)

Szabó Gy. (2008): A települési önkormányzatok környezetvédelmi feladatai. Debreceni Egyetem, Debrecen

Szigeti E. (2014): Újra járás. In: Horváth M. T. (szerk.): Külön utak. Közfeladatok megoldásai. Dialóg Campus, Budapest, Pécs, 255-290.

Szilágyi E. (2015): Mennyit ér a közszolgáltatás? A hulladékkezelési díjszabás alkotmányos problémái. kozjavak.hu - Az MTA-DE Közszolgáltatási Kutatócsoport blogja, 2015. október 4.

http://www.kozjavak.hu/sites/default/files/szilagyi.emese_mennyit_e_r_a_kozszolgaltatas.pdf (Letöltés: 2016. január 21.)

Szilágyi J. E. (2012): Vízjog. Aktuális kihívások a vizek jogi szabályozásában. Miskolci Egyetem, Miskolc

Szilágyi J. E. (2014): A magyar víziközmü-szolgáltatók integrációja jogi nézőpontból. Pro Futuro, 1., 144-162.

Szirmai V. (2005): Globális klímaváltozás és a társadalmi biztonság. Magyar Tudomány, 7., 849-856.

Szirmai V. (2006): Társadalmilag fenntartható városfejlődés a kelet-közép-európai történelmi belvárosokban. In: Bulla M., Guzli P. (szerk.): Fenntartható fejlődés Magyarországon. Új Mandátum Kiadó, Budapest, 402-419.

Szlávik J. (2005): Fenntartható környezet- és erőforrás-gazdálkodás. KJK-KERSZÖV, Budapest

Taylor, S. J., Bogdan, R. (1998): Introduction to qualitative research methods. John Wiley \& Sons, New York, Chichester, Weiheim, Brisbane

Tosics I. (2006): A nagyvárosok fenntartható fejlődése és Budapest jövőképe. In: Bulla M., Guzli P. (szerk.): Fenntartható fejlódés Magyarországon. Új Mandátum Kiadó, Budapest, 420-443.

VAHAVA (2010): VAHAVA-jelentés. Budapest http://www.vahavahalozat.hu/files/vahava-2010-12korrigalt-2.pdf (Letöltés: 2016. január 28.)

Varjú V. (2010): A környezeti politika fejlesztéspolitikába történő integrációja - a stratégiai környezeti vizsgálat. Doktori értekezés. Pécsi Tudományegyetem, Pécs

Védegylet Egyesület (2010): Környezeti igazságosság Magyarországon. Zárótanulmány. http://kornyezetiigazsagossag.hu/zarotanulmany.pdf (Letöltés: 2016. január 21.)

Vicsek L. (2006): Fókuszcsoport. Osiris, Budapest

Zsibók Zs. (szerk.) (2013): Önkormányzati energetikai fejlesztések. Nemzetközi körkép és a dél-dunántúli tapasztalatok. MTA KRTK Regionális Kutatások Intézete, Pécs 